\title{
KAJIAN PRA REVITALISASI PASAR BERORIENTASI KESEJAHTERAAN, KENYAMANAN DAN KEINDAHAN (Kasus Revitalisasi Pasar Banjarsari Kota Pekalongan)
}

\author{
Siti Nurhayati*, Suryani, Shinta Dewi Rismawati, P. A. Christianto, \\ Vita Nur Latief, Mujiyono, Sobrotul Imtikhanah \\ Dewan Riset Daerah Kota Pekalongan \\ Korespondensi: nurhayati.ms99@gmail.com
}

\begin{abstract}
One of the major trade facilities in Pekalongan City is the Banjarsari Central Market located on Jalan Sultan Agung, Sampangan, Pekalongan Timur District, Pekalongan City. This main market is located in one with the Borobudur Mall and Giant Supermarket. Banjarsari Market has 3 floors and consists of 1,156 kiosks, 171 shops and 2,701 shops. The first floor is mostly occupied by textile traders, the second and third floors are occupied by various types of merchandise, both culinary, vegetable, meat, and grocery stores. This condition changed completely after the Pasar Banjarsari fire occurred on Monday, February 26, 2018 and could only be totally extinguished after 30 hours of the incident. After the fire, the economic activities that had been centralized in the Banjarsari Central Market for a while were relocated to Jalan Patiunus and its surroundings where traders were accommodated in temporary barracks and semi-permanent. The conditions at the temporary shelter location naturally experience various obstacles in the implementation of trade transactions such as heat, huddle, pedestrian and buyers are less comfortable, and disrupt the fruit stalls that already existed on Jalan Patiunus. This condition must be immediately followed up with the policy of Pekalongan City Government to revitalize the rebuilding of the Iduk Banjarsari Market after the fire. To support the Banjarsari Main Market revitalization efforts, through the research activities, a pre-revitalization study of the Banjarsari Main Market will be conducted, so that it can provide recommendations to the Pekalongan City Government regarding the needs and forms of buildings, availability of social facilities, environmental maintenance, and convenience for traders and buyers .
\end{abstract}

Keywords: Banjarsari market, Pekalongan City Government, Pre revitalization, Recommendations

\begin{abstract}
ABSTRAK
Salah satu sarana perdagangan besar yang ada di Kota Pekalongan adalah Pasar Induk Banjarsari yang terletak di Jalan Sultan Agung, Sampangan, Kecamatan Pekalongan Timur, Kota Pekalongan. Pasar induk ini lokasinya menjadi satu dengan Mall Borobudur dan Swalayan Giant. Pasar Banjarsari memiliki 3 lantai dan terdiri dari 1.156 kios, 171 toko dan 2.701 los. Lantai pertama sebagian besar ditempati oleh pedagang tekstil, lantai kedua dan ketiga ditempati berbagai macam jenis dagangan, baik kuliner, sayur, daging, maupun toko kelontong. Kondisi ini berubah total setelah terjadi kebakaran Pasar Banjarsari pada Senin, 26 Februari 2018 dan baru bisa padam total setelah 30 jam dari kejadian. Pasca terjadi kebakaran, kegiatan ekonomi yang tadinya terpusat di Pasar Induk Banjarsari untuk sementara waktu di relokasi ke Jalan Patiunus dan sekitarnya di mana para pedagang ditampung pada barak-barak yang sifatnya sementara dan bentuknya semi permanen. Kondisi di lokasi penampungan sementara tentu saja mengalami berbagai kendala dalam pelaksanaan transaksi perdagangan seperti panas, berjubel, pedangan dan pembeli kurang nyaman, serta mengganggu kioskios buah yang sudah ada sebelumnya di Jalan Patiunus. Kondisi ini harus segera ditindaklanjuti dengan kebijakan Pemerintah Kota Pekalongan untuk melakukan revitalisasi pembangunan kembali Pasar Iduk Banjarsari pasca kebakaran. Untuk mendukung upaya revitalisasi Pasar Induk Banjarsari maka melalui kegiatan penelitian akan dilakukan kajian pra revitalisasi Pasar Induk Banjarsari, sehingga dapat memberikan rekomendasi kepada Pemerintah Kota Pekalongan terkait dengan kebutuhan dan bentuk bangunan, ketersediaan sarana sosial, pemeliharaan lingkungan, serta kenyamanan bagi pedagang dan pembeli dalam bertransaksi.
\end{abstract}

Kata Kunci: Pasar Banjarsari, Pemkot Pekalongan, Pra revitalisasi, Rekomendasi 


\section{PENDAHULUAN}

Selain kota Batik, kota Pekalongan dikenal juga sebagai kota Perdagangan, sehingga menjadi konsekuensi bagi Pemerintah Kota Pekalongan untuk mengupayakan penyediaan sarana dan prasarana perdagangan yang diperlukan bagi pengembangan usaha perdagangan yang ada, diantaranya adalah memfasilitasi tersedianya "pasar". Pasar merupakan lembaga ekonomi tempat bertemunya pembeli dan penjual baik secara langsung maupun tidak langsung untuk melakukan transaksi perdagangan (pasal 1 Undang-Undang Nomor 7 tahun 2014 tentang Perdagangan).

Kota Pekalongan memiliki banyak fasilitas perdagangan, selain pasar tradisional, ada juga fasilitas perdagangan modern di Kota Pekalongan, seperti supermarket dan mini market. Saat ini di Kota Pekalongan terdapat 11 pasar tradisional, 6 pasar swalayan (supermarket), dan 5 mini market dengan sekitar 25 cabang. Sarana perdagangan sebagaimana disebutkan di atas adalah sebagai berikut:

a. Supermarket (pasar swalayan)

1) Plaza Pekalongan (Hypermart \& Matahari Departement Store)

2) Mall Pekalongan (Giant \& Borobudur Departement Store)

3) Dupan Square

4) Carrefour Mega Centre (CMC) Pekalongan

5) Pekalongan Square (Ramayana Departement Store dan Robinson)

6) Superindo

b. Pasar Tradisional

1) Pasar Batik Grosir Setono

2) Pasar Podosugih

3) Pasar Anyar

4) Pasar Pagi Kraton

5) Pasar Induk Banjarsari

6) Pasar Poncol

7) Pasar Sugihwaras

8) Pasar Induk Banyuurip

9) Pasar Induk Grogolan Baru

10) Pasar Panjang Wetan

11) Pasar Induk Kuripan

c. Minimarket :

Jumlah minimarket diKota Pekalongan saat ini sudah mencapai 25 minimarket, baik mini market yang didirikan oleh perorangan maupun bisnis jejaring seperti Alfamart dan Indomaret.

Dalam pasar tradisional transaksi barang tidak dapat ditarik menurut perspektif dikhotomis "keuntungan yang maksimal, kerugian yang minimal". Seorang pedagang tidak sekedar menerima uang dan pihak lain menerima barang, tetapi terdapat kebutuhan sosial yang ingin didapat dari pihak lain, yakni penghargaan yang bersifat timbal-balik berlangsung dalam hubungan yang setara, terjalin ikatan hubungan personal emosional. Demikian juga dengan konsumen/pelanggan tidak semata mendapat sesuatu barang yang diperlukan, tetapi terdapat "kepuasan" lain yang diperlukan, diantaranya tempat dan dengan siapa penjual yang dihadapinya. Dalam budaya masyarakat timur, berbelanja sambil bersosialisasi adalah lebih menjadi preferensi dari pada berbelanja secara 
individualis, maka berbelanja sambil tukar bicara adalah salah satu modus pemuas kebutuhan, atau sebagai salah satu bagian yang menyertai komoditi yang harus dipenuhi.

Dalam penelitian Leksono (2009) menemukan bahwa pasar tradisional adalah sebagai modus interaksi sosial-budaya bahkan pasar juga mengandung fungsi religius sebagai sarana ibadah. Selain itu pasar tradisional dengan harga luncurnya padanya terkandung transaction cost dan bahkan asymmetric information. Dari korbanan waktu, proses tawar-menawar adalah merupakan biaya transaksi, akan tetapi jika didalamnya berlangsung pula proses komunikasi yang dapat menunjukkan kejelasan tentang karakter obyek barang yang diperjual belikan serta terjadi proses penyesuaian harga maka asymmetric information akan menyusut jauh. Disini proses transaksi mempunyai peluang akan berkelanjutan berdasarkan interaksi sosial yang terjadi karena diantara keduanya menjadi saling kenal.

Salah satu sarana perdagangan yang ada di Kota Pekalongan adalah pasar induk Banjarsari yang terletak di jalan Sultan Agung, Sampangan, Kecamatan Pekalongan Timur, Kota pekalongan. Pasar induk ini sudah mengalami renovasi menjadi pasar tradisional yang modern dan sangat representatif karena lokasinya menjadi satu dengan mall Borobudur dan swalayan Giant. Pasar Banjarsari merupakan sebuah pasar induk di Kota pekalongan yang memiliki tiga lantai. Dari 3 lantai tersebut terdapat 4.028 bangunan kios, los maupun toko, terdiri atas 171 toko, 1.156 kios, dan 2.701 los. Lantai pertama yang sebagian besar untuk pedagang tekstil, terdapat 1.128 bangunan yang terdiri atas 111 toko, 447 los, dan 570 kios. Sedangkan lantai dua berisi 1.761 bangunan yang terdiri atas 48 toko, 439 kios dan 1.274 los. Untuk lantai 3, terdapat 1.139 bangunan terdiri atas 12 toko, 270 kios dan 857 los. Untuk lantai 2 dan 3, dihuni berbagai macam jenis dagangan, baik kuliner, sayur, daging, maupun toko kelontong. Ada juga pedagang pakaian dan sepatu (jateng.tribunnews.com/.../4028-lapak-pedagang-pasar-banjarsaripekalongan-habis-te...,26 Feb 2018)
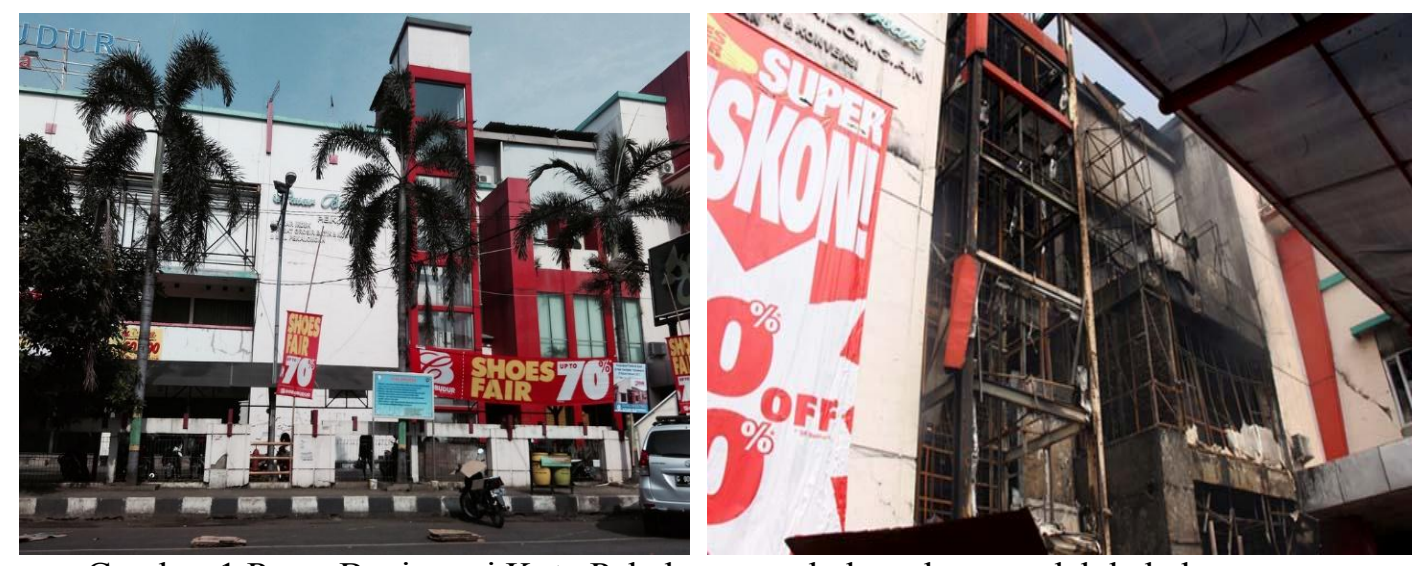

Gambar 1 Pasar Banjarsari Kota Pekalongan sebelum dan sesudah kebakaran

Pasca terjadi kebakaran di pasar induk Banjarsari pada bulan Februari 2018 yang lalu, kegiatan ekonomi yang tadinya terpusat di pasar induk Banjarsari untuk sementara waktu di relokasi ke jalan Patiunus dan sekitarnya di mana para pedagang ditampung pada barak-barak yang sifatnya sementara dan bentuknya semi permanen. Kondisi di lokasi penampungan sementara tentu saja mengalami berbagai kendala dalam pelaksanaan transaksi perdagangan seperti panas, berjubel, pedangan dan pembeli kurang nyaman, serta mengganggu kios-kios buah yang sudah ada sebelumnya di jalan Patiunus. Kondisi ini harus segera ditindaklanjuti dengan kebijakan Pemerintah Kota Pekalongan 
untuk melakukan revitalisasi pembangunan kembali pasar induk Banjarsari pasca kebakaran.

\section{PENGUMPULAN DATA}

Data-data yang diperlukan dalam penelitian ini, dikumpulkan dengan menggunakan beberapa cara, yaitu:

\subsection{Wawancara}

Responden yang bisa dijaring dengan pendekatan snowball sampling meliputi responden pedagang eks pasar banjarsari dan responden konsumen, dengan jumlah masing-masing sebanyak 22 pedagang dan 27 konsumen.

\subsection{Responden Pedagang}

Sampel pedagang sebanyak 22 orang terdiri atas 6 orang pedagang pria dan 16 orang pedagang wanita dengan kisaran usia antara 25 tahun s/d 56 tahun. Para pedagang ini sebagian besar berasal dari wilayan Kota Pekalongan, dan hanya beberapa yang berasal dari Kabupaten Batang (Kalisari, dan Kalibeluk), serta berasal dari Kabupaten Pekalongan (Kedungwuni). Produk yang dijual pedagang sampel meliputi pakaian/fashion, kerudung, sarung, batik, sembako, sepatu/sandal, makanan ringan, sayuran dan bumbu dapur, perabot rumah tangga, daging ayam, dan jamu.

Tempat berjualan pedagang sampel meliputi toko, kios dan los, di mana 14 pedagang menempati tempat jualan di lantai 1, 7 orang sampel menempati tempat jualan di lantai 2, dan 1 orang sampel pedagang berjualan di lantai 3. Status kepemilikan tempat berjualan menunjukkan bahwa sebanyak 12 pedagang menempati tempat jualan milik sendiri, dan 10 pedagang menempati tempat jualan dengan sewa (kontrak). Pedagang sampel rata-rata sudah cukup lama berjualan di pasar Banjarsari, bahkan ada 2 orang pedagang yang sudah berjualan selama sekitar 30 tahun.

Omset penjualan rata-rata per hari (sebelum musibah kebakaran pasar) dari sampel pedagang berkisar antara Rp 300.000,- (terendah untuk pedagang sayuran dan jamu), dan Rp 4.500.000,0 (tertinggi untuk jenis pakaian/fashion, dan batik). Ketika ditanyakan kerugian yang di derita akibat kebakaran pasar, mereka menyatakan kerugiannya sangat besar, terutama untuk pedagang pakaian, batik, dan sejenisnya; bahkan ada yang menyatakan kerugiannya mencapai milyaran rupiah.

\subsection{Responden Konsumen}

Sampel konsumen yang bisa diambil adalah 27 orang, terdiri atas 4 orang pria dan 23 orang wantia, dengan usia berkisar antara 20 tahun s/d 58 tahun. Konsumen sebagian berasal dari wilayah Kota Pekalongan (kebanyakan merupakan konsumen akhir), dan sebagian berasal dari Kabupaten Pekalongan (Bojong, Wonokerto, Bligo, Kedungwuni, Pekajangan) dan juga ada yang berasal dari Kabupaten batang (Tulis, Setono). Mereka yang berasal dari luar Kota Pekalongan kebanyakan merupakan konsumen antara (membeli untuk dijual/diolah lagi).

Jenis barang yang paling sering dibeli konsumen adalah bahan makanan/sayuran dan bumbu dapur lainnya, yang umumnya dibeli oleh konsumen antara di mana mereka akan menjualnya lagi baik melalui proses pengolahan terlabih dahulu maupun tidak. Mereka ini adalah konsumen yang berbelanja hampir tiap hari (kisaran antara 1 sampai 3 hari sekali). 


\subsection{Studi Literatur}

Mempelajari isi materi yang disampaikan oleh Agus S. Ekomadyo, pada acara Temu Ilmiah IPLBI tahun 2012.

\subsection{Focus Group Discussion (FGD)}

Masukan-masukan yang diberikan dari beberapa dinas terkait pada acara FGD yang dilaksanakan pada hari Selasa (13 November 2018), jam 13.00 dan bertempat di Ruang Asisten II Setda Kota Pekalongan.

\section{HASIL DAN PEMBAHASAN}

\subsection{Penilaian Responden Terhadap Fasilitas Pasar (Sebelum Kebakaran)}

\subsubsection{Penilaian Pedagang}

Dari sebanyak 22 orang sampel pedagang, hampir semua menyatakan bahwa setiap hari ada petugas administrasi pasar yang berkeliling mengontrol situasi pasar, hanya 1 orang yang tidak memberi respon atas pertanyaan ini. Disamping itu juga mayoritas pedagang menyatakan bahwa petugas administrasi pasar menjalin hubungan dan komunikasi yang baik dengan para pedagang, dan hanya ada 4 orang pedagang yang menyatakan hubungan petugas administrasi pasar dengan para pedagang tidak baik.

Ketika kepada para pedagang ditanyakan mengenai mudah/tidaknya pengurusan ijin penggunaan tempat berdagang, mayoritas menyatakan mudah, dan hanya 2 orang pedagang menyatakan pengurusan ijin tempat berdagang sulit. Demikian halnya ketika ditanyakan apakah ada permasalahan yang berarti selama menempati tempat berdagang, mayoritas mengatakan tidak ada masalah. Sedangkan yang menyatakan ada masalah hanya 4 orang, 3 diantaranya mempermasalahkan mushola dan toilet yang kurang bersih, dan 1 orang menyatakan bahwa di lantai 2 kadang-kadang banjir. Menurut mereka yang menyatakan ada masalah tersebut juga telah menyampaikan kepada pihak pengelola pasar, namun belum ada penyelesaian/solusi yang baik.

Selanjutnya kepada pedagang yang dijadikan sampel juga diminta memberikan penilaian terhadap fasilitas yang ada sesuai dengan persepsi penilaian mereka secara individu. Penilaian pedagang sampel terhadap berbagai fasilitas yang disediakan di lingkungan pasar Banjarsari (sebelum kebakaran) dilakukan dengan instrument berupa kuesioner yang diukur dengan skala Likert dengan kreteria penilaian sangat setuju (SS), setuju (S), tidak memberi pendapat (TB), kurang setuju (KS), dan tidak setuju (TS). Penilaian pedagang atas fasilitas yang tersedia diringkas dalam tabel sebagai berikut.

Tabel 1 Penilaian Pedagang atas Fasilitas Pasar Sebelum Kebakaran

\begin{tabular}{c|l|c|c|c|c|c|c}
\multirow{2}{*}{ No } & \multicolumn{5}{|c|}{ Jawaban } & \multirow{2}{*}{ Jumlah } \\
\cline { 3 - 7 } & \multicolumn{1}{|c|}{ SS Pertanyaan } & S & TB & KS & TS & \\
\hline 1 & Luas tempat berjualan mencukupi & 4 & 11 & 1 & 5 & 0 & $\mathbf{2 1}$ \\
\hline 2 & Kondisi bangunan baik & 6 & 13 & 0 & 2 & 0 & $\mathbf{2 1}$ \\
\hline 3 & $\begin{array}{l}\text { Lokasi pasar strategis dan mudah dijangkau dengan } \\
\text { transportasi umum }\end{array}$ & 8 & 13 & 0 & 0 & 0 & $\mathbf{2 1}$ \\
\hline 4 & Penerangan (listrik) mencukupi & 5 & 12 & 0 & 4 & 0 & $\mathbf{2 1}$ \\
\hline 5 & Fasilitas air bersih dan MCK mencukupi dan lancar & 1 & 8 & 0 & 9 & 3 & $\mathbf{2 1}$
\end{tabular}




\begin{tabular}{c|l|c|c|c|c|c|c}
\multirow{2}{*}{ Item Pertanyaan } & \multicolumn{9}{c}{ Jawaban } & \multirow{2}{*}{ Jumlah } \\
\cline { 3 - 7 } No & SS & S & TB & KS & TS & \\
\hline 6 & Tersedia tempat ibadah dengan kondisi baik & 6 & 8 & 3 & 3 & 1 & $\mathbf{2 1}$ \\
\hline 7 & Ruang kosong untuk melayani konsumen cukup luas & 1 & 4 & 4 & 12 & 0 & $\mathbf{2 1}$ \\
\hline 8 & $\begin{array}{l}\text { Petugas keamanan pasar mencukupi, dan bekerja dengan } \\
\text { baik }\end{array}$ & 4 & 12 & 0 & 2 & 3 & $\mathbf{2 1}$ \\
\hline 9 & Tersedia fasilitas dan petugas kesehatan dengan cukup & $\mathbf{0}$ & $\mathbf{2}$ & $\mathbf{2}$ & $\mathbf{4}$ & $\mathbf{1 3}$ & $\mathbf{2 1}$ \\
\hline & Jumlah & $\mathbf{3 5}$ & $\mathbf{8 3}$ & $\mathbf{1 0}$ & $\mathbf{4 1}$ & $\mathbf{2 0}$ &
\end{tabular}

Dari hasil jawaban pedagang sebagaimana tersaji pada tabel 1 di atas, bisa diketahui bahwa secara umum pedagang menilai fasilitas yang tersedia sudah cukup baik, kecuali fasilitas air bersih/MCK, ketersediaan ruang kosong untuk melayani konsumen, dan ketersediaan fasilitas dan petugas kesehatan dinilai kurang oleh pedagang sampel. Secara rinci hasil penelitian menunjukkan hal-hal sebagai berikut:

1. Pedagang syang menyatakan setuju dan sangat setuju mengenai kecukupan luas tempat berjualan berjumlah 15 orang $(71,4 \%)$. Hal ini menunjukkan bahwa secara umum pedagang menganggap bahwa luas tempat berjualan mencukupi dan tidak mempermasalahkan dengan luas tempat berjualan yang tersedia

2. Pedagang yang menyatakan setuju dan sangat setuju terhadap baiknya kondisi bangunan pasar berjumlah 19 orang (90,5 \%). Hal ini mengandung arti bahwa bangunan fisik pasar sudah cukup baik dan representative untuk malaksanakan kegiatan perdagangan.

3. Semua pedagang (100\%) menyatakan setuju dan sangat setuju dengan lokasi pasar strategis dan mudah dijangkau dengan transportasi umum. Jika dilihat dari lokasinya memang letak pasar Banjarsari sangat strategis sehingga mudah dijangkau dengan transportasi umum dari berbagai arah baik yang menggunakan kendaraan pribadi (mobil, motor, atau sepeda), maupun yang menggunakan transportasi umum (angkutan kota dan becak).

4. Pedagang yang menyatakan setuju dan sangat setuju dengan kecukupan penerangan (listrik) berjumlah 17 orang (80,95\%). Hal ini menunjukkan bahwa tidak ada masalah dengan penerangan yang dibutuhkan oleh para pedagang.

5. Pedagang yang menyatakan setuju dan sangat setuju dengan kecukupan dan kelancaran penyediaan air bersih dan MCK hanya sebanyak 9 orang (42,85\%), sehingga masih lebih banyak yang menyatakan kurang dan tidak setuju. Tentu saja penilaian seperti ini harus memperoleh prioritas perhatian dari pengelola pasar untuk segera dilakukan pembenahan-pembenahan yang perlu.

6. Pedagang yang menyatakan setuju dan sangat setuju dengan rersedianya tempat ibadah dengan kondisi baik berjumlah 14 orang $(66,67 \%)$, sedangkan sisanya (33,33\%) menyatakan kurang setuju.

7. Pedagang yang menyatakan setuju dan sangat setuju dengan tersedianya ruang kosong untuk melayani konsumen cukup luas hanya berjumlah 5 orang $(23,81 \%)$, ini menunjukkan bahwa sebagian besar 
pedagang merasa ruang kosong (space) untuk melayani pembeli kurang sehingga mereka tidak bisa leluasa melayani dengan nyaman.

8. Pedagang yang menyatakan setuju dan sangat setuju dengan kecukupan petugas keamanan pasar berjumlah 16 orang $(76,19 \%)$. Hal ini menunjukkan bahwa secara umum keamanan barang-barang yang ada dan keamanan bertransaksi cukup terjamin.

9. Pedagang yang menyatakan setuju dan sangat setuju dengan tersedianya fasilitas dan petugas kesehatan dengan cukup hanya berjumlah 2 orang $(9,52 \%)$. Hal ini menginikasikan bahwa mayoritas pedagang menilai belum adanya fasilitas dan petugas keamanan yang mencukupi, dan pengelola pasar harus memprioritaskan penyediaan fasilitas dan petugas kesehatan yang mencukupi.

\subsubsection{Penilaian Konsumen.}

Sebagaimana halnya dengan pedagang, konsumen yang dijadikan sampel juga diminta memberikan penilaian terhadap fasilitas yang ada sesuai dengan persepsi penilaian mereka secara individu. Penilaian konsumen sampel terhadap berbagai fasilitas yang disediakan di lingkungan pasar Banjarsari (sebelum kebakaran) dilakukan dengan instrument berupa kuesioner yang diukur dengan skala Likert dengan kreteria penilaian sangat setuju (SS), setuju (S), tidak memberi pendapat (TB), kurang setuju (KS), dan tidak setuju (TS). Penilaian yang diberikan oleh sebanyak 27 konsumen sampel atas fasilitas yang tersedia diringkas dalam tabel 2 sebagai berikut.

Tabel 2 Penilaian Konsumen atas Fasilitas Pasar Sebelum Kebakaran

\begin{tabular}{c|l|c|c|c|c|c|c}
\multirow{2}{*}{ No } & \multicolumn{1}{|c|}{ Item Pertanyaan } & \multicolumn{3}{c}{ Jawaban } & \multirow{2}{*}{ Jumlah } \\
\cline { 3 - 6 } & & SS & S & TB & KS & TS & \\
\hline 1 & Luas tempat berjualan mencukupi & 3 & 17 & 1 & 3 & 3 & $\mathbf{2 7}$ \\
\hline 2 & Kondisi bangunan baik & 2 & 11 & 0 & 10 & 4 & $\mathbf{2 7}$ \\
\hline 3 & $\begin{array}{l}\text { Lokasi pasar strategis dan mudah dijangkau dengan } \\
\text { transportasi umum }\end{array}$ & 8 & 18 & 0 & 1 & 0 & $\mathbf{2 7}$ \\
\hline 4 & Penerangan (listrik) mencukupi & 3 & 9 & 5 & 6 & 4 & $\mathbf{2 7}$ \\
\hline 5 & Fasilitas air bersih dan MCK mencukupi dan lancar & 2 & 1 & 6 & 10 & 8 & $\mathbf{2 7}$ \\
\hline 6 & Tersedia tempat ibadah dengan kondisi baik & 3 & 8 & 3 & 7 & 6 & $\mathbf{2 7}$ \\
\hline 7 & Ruang kosong untuk melayani konsumen cukup luas & 0 & 5 & 3 & 13 & 6 & $\mathbf{2 7}$ \\
\hline & Jumlah & $\mathbf{2 1}$ & $\mathbf{6 9}$ & $\mathbf{1 8}$ & $\mathbf{5 0}$ & $\mathbf{3 1}$ &
\end{tabular}

Berdasarkan hasil penilain konsumen atas fasilitas yang ada di lingkungan pasar sebelum terjadi kebakaran yang sudah diringkas pada tabel 2 di muka bisa disimpulkan beberapa hal sebagai berikut :

1. Sebanyak 20 orang konsumen $(74,07 \%)$ konsumen menyatakan setuju dan sangat setuju bahwa luas tempat berjualan yang ada pada pedagang sudah mencukupi.

2. Sebanyak 13 orang konumen $(48,15 \%)$ menyatakan setuju dan sangat setuju bahwa bangunan fisik pasar cukup baik, sedangkan 14 orang konsumen $(51,85 \%)$ menyatakan kurang dan tidak setuju bahwa bangunan fisik pasar dalam kondisi baik.

3. Sebanyak 26 orang konsumen $(96,30 \%)$ menyatakan setuju dan sangat setuju bahwa lokasi pasar strategis dan mudah dijangkau 
dengan transportasi umum, dan hanya 1 orang $(3,70 \%)$ menyatakan kurang setuju.

4. Konsumen yang menyatakan setuju dan sangat setuju dengan kecukupan alat penerangan (listrik) berjumlah 12 orang (44,44\%), sedang yang menyatakan kurang dan tidak setuju sebanyak 10 orang $(37,03 \%)$. Sisanya sebanyak 5 orang konsumen $(18,53 \%)$ tidak menyampaikan pendapat dikarenakan mereka berbelanja pada siang hari dan pada toko yang berada disebelah luar bangunan pasar sehingga tidak tahu kondisi di dalam pasar.

5. Hanya 3 orang konsumen $(11,11 \%)$ yang menyatakan setuju dan sangat setuju dengan ketersediaan fasilitas air bersih dan MCK mencukupi dan lancar, dan sebagian besar menyatakan fasilitas air bersih dan MCK kurang/tidak mencukupi.

6. Konsumen yang menyatakan setuju dan sangat setuju atas ketersediaan tempat ibadah dengan kondisi baik berjumlah 11 orang $(40,74 \%)$, dan sisanya menyatakan kurang/tidak setuju serta tidak memberi pendapat.

7. Konsumen yang menyatakan setuju dan sangat setuju atas ketersediaan ruang kosong yang cukup luas untuk melayani konsumen hanya berjumlah 5 orang $18,52 \%$ ), dan sisanya menyatakan kurang dan tidak setuju. Hal ini menunjukkan bahwa terjadi kekurang nyamanan diantara para konsumen ketika melakukan transaksi berbelanja. Tentu saja kondisi seperti ini harus diperhatikan ketika melakukan perbaikan, yakni harus memberikan space yang cukup bagi konsumen untuk berbelanja secara lebih nyaman.

\subsection{Harapan/Saran Responden Jika Pasar Dibangun kembali}

Sampai saat ini para pedagang yang terdampak kebakaran pasar Banjarsari masih merasakan kondisi psikologis yang kurang mengenakkan baik akibat kerugian yang harus ditanggung maupun akibat kehilangan tempat berjualan. Lapak-lapak yang disediakan di pasar darurat dirasakan kurang memenuhi syarat seperti terlalu sempit, suasana panas, dan berdesakan, sehingga dirasakan tidak nyaman baik oleh pedagang maupun konsumen. Oleh karena itu baik para pedagang maupun konsumen memberikan berbagai saran, masukan, serta harapanharapan mereka jika pasar banjarsari kembali dibangun.

Berbagai saran/masukan dan harapan dari para pedagang dan konsumen disajikan secara ringkas pada tabel berikut ini.

Tabel 3 Saran/Masukan, dan Harapan Para Pedagang

\begin{tabular}{c|l|ll} 
No & \multicolumn{1}{|c}{ Kelompok } & \multicolumn{1}{c}{ Saran/Masukan, dan Harapan } \\
\hline 1 & $\begin{array}{l}\text { Saran terkait dengan fasilitas } \\
\text { toko/kios/los }\end{array}$ & 1. $\begin{array}{l}\text { Ukuran toko/kios agar disesuaikan dengan yang dimiliki } \\
\text { sebelum kebakaran }\end{array}$ \\
& 2. $\begin{array}{l}\text { Ukuran los agar diperluas lagi } \\
\text { 3. }\end{array}$ & $\begin{array}{l}\text { Minta agar ada pengundian sebelum menempati } \\
\text { toko/kios/los }\end{array}$ \\
& 4. $\begin{array}{l}\text { Lorong jangan terlalu sempit dan agar lebih banyak } \\
\text { ventilasi }\end{array}$ \\
& 5embayaran listrik pakai token prabayar agar tidak mudah \\
mati
\end{tabular}




\begin{tabular}{|c|c|c|}
\hline No & Kelompok & Saran/Masukan, dan Harapan \\
\hline & & $\begin{array}{l}\text { 6. Pedagang lama jangan membayar lagi karena sebelum } \\
\text { kebakaran sudah hak milik } \\
\text { 7. Agar dibangun } 2 \text { lantai saja } \\
\text { 8. Toko di bagian belakang agar sama bagusnya dengan di } \\
\text { bagian depan }\end{array}$ \\
\hline 2 & $\begin{array}{l}\text { Saran terkait dengan fasilitas umum } \\
\text { (MCK, Mushola, kebersihan, dll) }\end{array}$ & $\begin{array}{l}\text { 1. Toilet dan Mushola agar dijaga kebersihannya, dan perlu } \\
\text { diperbanyak (bila memungkinkan setiap bagian ada } \\
\text { Mushola) } \\
\text { 2. Lift barang agar dihidupkan lagi } \\
\text { 3. Keamanan perlu ditingkatkan dan preman dihilangkan } \\
\text { 4. Penataan parkir lebih ditertibkan lagi } \\
\text { 5. Petunjuk jalan/blok perlu ditambah lagi }\end{array}$ \\
\hline 3 & $\begin{array}{l}\text { Saran terkait dengan pembayaran } \\
\text { tempat berjualan }\end{array}$ & $\begin{array}{l}\text { 1. Pembayaran toko/kios dicicil tahunan saja, jangan pakai } \\
\text { EDC karena mahal } \\
\text { 2. Pembayaran karcis jangan di pihak ketigakan, tapi } \\
\text { disediakan loket pembayaran saja } \\
\text { 3. Jangan ada lagi preman yang menarik uang keamanan }\end{array}$ \\
\hline 4 & $\begin{array}{l}\text { Saran terkait dengan pelayanan oleh } \\
\text { pengelola pasar }\end{array}$ & $\begin{array}{l}\text { 1. Pengelola pasar jangan kalah sama preman } \\
\text { 2. Pengaduan pedagang harus direspon dengan cepat } \\
\text { 3. Pelayanan kepada pengguna toko/kios/los agar lebih } \\
\text { ditingkatkan }\end{array}$ \\
\hline 5 & $\begin{array}{l}\text { Saran untuk Pemerintah Kota } \\
\text { Pekalongan }\end{array}$ & $\begin{array}{l}\text { 1. Pasar agar terpisah dari mall agar seimbang } \\
\text { 2. Agar segera dibangun lagi karena di pasar darurat } \\
\text { pendapatan pedagang minim } \\
\text { 3. Pemerintah agar lebih memperhatikan nasib para pedagang } \\
\text { 4. Pembayaran angsuran langsung ke Bank Pasar saja agar } \\
\text { lebih tertib administrasi } \\
\text { 5. Pembangunan pasar agar menyatu seluruh perlengkapannya } \\
\text { 6. Prosedur pembayaran agar dipermudah } \\
\text { 7. Hydrant dan alat pemancar air yang tidak berfungsi agar } \\
\text { difungsikan lagi } \\
\text { 8. Pemerintah jangan janji-janji saja tapi segera dibuktikan } \\
\text { pembangunannya dan lebih memperhatikan pedagang kecil }\end{array}$ \\
\hline 6 & Saran lainnya & $\begin{array}{l}\text { 1. Pasar dan mall Borobudur sebaiknya jangan berdampingan } \\
\text { 2. Pembangunan gedung disesuaikan dengan adat istiadat } \\
\text { 3. Agar dibangun pasar yang bersih seperti di TV }\end{array}$ \\
\hline
\end{tabular}

Tabel 4 Saran/Masukan, dan Harapan Konsumen

\begin{tabular}{|c|c|c|}
\hline No & Kelompok & Saran/Masukan, dan Harapan \\
\hline 1 & $\begin{array}{l}\text { Saran terkait dengan fasilitas } \\
\text { toko/kios/los }\end{array}$ & $\begin{array}{l}\text { 1. Toko agar lebih bersih dan penerangan cukup } \\
\text { 2. Pasar dibikin tidak pengap dan lorong diperlebar agar } \\
\text { pembeli nyaman } \\
\text { 3. Kios makanan jangan di lantai atas } \\
\text { 4. Kios sayuran agar dilantai bawah } \\
\text { 5. Pembangunan agar memperhatikan penataan lorong untuk } \\
\text { pejalan kaki dan sirkulasi udara yang baik } \\
\text { 6. Fasilitas toko agar ditingkatkan lagi dan letaknya jangan } \\
\text { muter-muter } \\
\text { 7. Agar dibagi per kelompok produk supaya konsumen mudah } \\
\text { mencari keperluannya }\end{array}$ \\
\hline 2 & $\begin{array}{l}\text { Saran terkait dengan fasilitas umum } \\
\text { (MCK, Mushola, kebersihan, dll) }\end{array}$ & $\begin{array}{l}\text { 1. MCK agar dijaga kebersihannya, layak pakai, dan tidak bau } \\
\text { 2. Mushola agar diperluas dan lebih bersih lagi } \\
\text { 3. Agar diberi kipas angin di Mushola } \\
\text { 4. Petugas kebersihan agar dioptimalkan fungsinya }\end{array}$ \\
\hline 3 & $\begin{array}{l}\text { Saran untuk Pemerintah Kota } \\
\text { Pekalongan }\end{array}$ & $\begin{array}{l}\text { 1. Pasar agar dibangun senyaman mungkin agar pembeli tidak } \\
\text { malas ke pasar yang baud an kotor } \\
\text { 2. Pemerintah agar mempersiapkan lahan untuk jualan } \\
\text { pedagang korban kebakaran } \\
\text { 3. Agar segera dibangun kembali karena banyak konsumen } \\
\text { yang kehilangan pedagang langganannya } \\
\text { 4. Penataan parker di depan pasar agar lebih tertib lagi untuk }\end{array}$ \\
\hline
\end{tabular}




\begin{tabular}{|c|c|c|}
\hline No & Kelompok & Saran/Masukan, dan Harapan \\
\hline & & $\begin{array}{l}\text { kelancaran pejalan kaki } \\
\text { 5. Agar dilakukan rekayasa lalulintas sehingga tidak macet } \\
\text { 6. Pembangunan kembali pasar agar mengutamakan fasilitas } \\
\text { umum demi kenyamanan pedagang dan pembeli }\end{array}$ \\
\hline 4 & Saran lainnya & $\begin{array}{l}\text { 1. Saluran air agar dibikin yang benar sehingga air tidak } \\
\text { menggenang di suatu tempat } \\
\text { 2. Pembangunan kembali pasar agar dibuat lebih megah } \\
\text { 3. Dilakukan penataan ulang parker di depan pasar dan } \\
\text { disepanjang jalan agar tidak mengganggu lalu lintas } \\
\text { 4. Sebaiknya lantai dasar untuk sayuran/sembako dan lantai } \\
\text { atas untuk pakaian, kosmetik, dll } \\
\text { 5. Semoga pembangunan kembali pasar Banjarsari menjadi } \\
\text { pusat belanja di Pekalongan }\end{array}$ \\
\hline
\end{tabular}

\section{PEMBAHASAN HASIL}

Berdasarkan hasil analisis terhadap semua data yang terkumpul dari responden pedagang serta responden konsumen/masyarakat, materi Agus S. Ekomadyo pada acara Temu Ilmiah IPLBI 2012 dan masukan-masukan dari dinas terkait pada kegiatan FGD tanggal 13 November 2018, maka ada 2 hal yang perlu diperhatikan dalam melakukan revitalisasi dan pembangunan kembali pasar Banjarsari, yaitu:

1) Pembangunan pasar Banjarsari, hendaknya memperhatikan pemenuhan aspek standar fungsional sebuah pasar tradisional.

2) Pembangunan pasar Banjarsari, tidak melupakan aspek ciri khas/karakter lokal Kota Pekalongan

Berikut penjelasan untuk masing-masing aspek di atas:

Tabel 5 Isu, tujuan dan kriteria pembangunan pasar Banjarsari Pekalongan yang hendaknya memperhatikan aspek standar fungsional sebuah pasar

\begin{tabular}{|c|c|c|}
\hline Isu & Tujuan & Kriteria \\
\hline 1. Pembayaran angsuran & $\begin{array}{l}\text { Memudahkan pedagang dalam } \\
\text { menyelesaikan kewajibannya }\end{array}$ & $\begin{array}{l}\text { Mempermudah prosedur pembayaran angsuran } \\
\text { (dapat menunjuk bank tertentu) }\end{array}$ \\
\hline $\begin{array}{l}\text { 2. Antisipasi dan } \\
\text { penangulangan bencana } \\
\text { kebakaran }\end{array}$ & $\begin{array}{l}\text { Mengantisipasi bencana } \\
\text { kebakaran yang sudah terjadi } \\
\text { beberapa kali }\end{array}$ & $\begin{array}{l}\text { 1. Perawatan rutin atas hydrant, pemancar air, } \\
\text { APAR dan instalasi listrik } \\
\text { 2. Ketersediaan APAR dan CCTV di beberapa } \\
\text { tempat strategis } \\
\text { 3. Pelatihan untuk petugas/pedagang pasar } \\
\text { dalam mempergunakan APAR } \\
\text { 4. Ketersediaan akses masuk untuk mobil } \\
\text { pemadam kebakaran dan tindakan evakuasi } \\
\text { saat darurat } \\
\text { 5. Mempertimbangkan bahwa iuran/ angsuran } \\
\text { yang dibebankan ke pedagang sudah } \\
\text { termasuk asuransi jiwa/asuransi bisnis untuk } \\
\text { pedagang }\end{array}$ \\
\hline $\begin{array}{l}\text { 3. Pasar Tradisional } \\
\text { berdampingan dengan } \\
\text { Pasar Modern } \\
\text { (Borobudur Mall) }\end{array}$ & $\begin{array}{l}\text { Mengoptimalkan fungsi pasar } \\
\text { tradisional Banjarsari }\end{array}$ & $\begin{array}{l}\text { 1. Adanya kemiripan fungsi pasar tradisional } \\
\text { dan pasar modern, sehingga untuk } \\
\text { mengoptimalkan fungsi pasar tradisional } \\
\text { maka sebaiknya pasar modern tidak } \\
\text { diletakan berdekatan dengan pasar } \\
\text { tradisional. } \\
\text { 2. Terkait dengan no.1, maka dapat dilakukan } \\
\text { peninjauan ulang perjanjian kerjasama } \\
\text { dengan pihak ketiga (Borodubur Mall), } \\
\text { sehingga tidak bermasalah secara hukum }\end{array}$ \\
\hline
\end{tabular}




\begin{tabular}{|c|c|c|}
\hline Isu & Tujuan & Kriteria \\
\hline $\begin{array}{l}\text { 4. Perlakuan untuk } \\
\text { pedagang lama }\end{array}$ & $\begin{array}{l}\text { Mempertimbangkan hak } \\
\text { pedagang yang sudah } \\
\text { memenuhi kewajibannya }\end{array}$ & $\begin{array}{l}\text { Mempertimbangkan pedagang yang memiliki } \\
\text { hak milik resmi atas kios/los di pasar Banjarsari } \\
\text { sebelum terbakar, untuk dapat menempati } \\
\text { kembali kios/losnya di pasar yang baru }\end{array}$ \\
\hline 5. Pembayaran listrik & $\begin{array}{l}\text { Mempermudah operasional } \\
\text { pemakaian listrik }\end{array}$ & $\begin{array}{l}\text { Pembayaran listrik menggunakan token } \\
\text { prabayar }\end{array}$ \\
\hline 6. Keamanan pasar & $\begin{array}{l}\text { Memberikan rasa aman dan } \\
\text { nyaman bagi para pedagang } \\
\text { dan masyarakat yang } \\
\text { berkunjung }\end{array}$ & $\begin{array}{l}\text { 1. Mengoptimalkan tenaga keamanan resmi } \\
\text { atau merekrut tenaga keamanan tambahan } \\
\text { yang disertai pelatihan yang baik } \\
\text { 2. Menggunakan seragam yang unik yang } \\
\text { berbeda dengan seragam satpol PP, sehingga } \\
\text { mudah dikenali }\end{array}$ \\
\hline $\begin{array}{l}\text { 7. Sistem pembayaran } \\
\text { retribusi }\end{array}$ & $\begin{array}{l}\text { Mengoptimalkan pemasukan } \\
\text { PAD ke kas pemerintah kota } \\
\text { Pekalongan }\end{array}$ & $\begin{array}{l}\text { Menerapkan teknologi informasi (e-retribusi) } \\
\text { dalam mengelola dan memonitoring } \\
\text { pembayaran retribusi }\end{array}$ \\
\hline 8. Lift barang & $\begin{array}{l}\text { Memudahkan pedagang } \\
\text { membawa barang-barang ke } \\
\text { toko/los nya yang berada di } \\
\text { lantai atas }\end{array}$ & $\begin{array}{l}\text { Menyediakan lift barang, seperti yang pernah } \\
\text { tersedia di pasar Banjarsari sebelum kebakaran }\end{array}$ \\
\hline $\begin{array}{l}\text { 9. Parkir dan rekayasa } \\
\text { lalu lintas }\end{array}$ & $\begin{array}{l}\text { Memberikan kenyamanan } \\
\text { bagi masyarakat yang } \\
\text { berkunjung dan } \\
\text { mempermudah pedagang } \\
\text { melakukan bongkar muat } \\
\text { barang barang dagangannya }\end{array}$ & $\begin{array}{l}\text { 1. Penataan area parkir yang lebih baik untuk } \\
\text { kendaraan beroda dua dan empat } \\
\text { 2. Penataan sirkulasi kendaraan keluar dan } \\
\text { masuk } \\
\text { 3. Ketersediaan parkir khusus untuk melakukan } \\
\text { bongkar muat } \\
\text { 4. Penetapan rekayasa lalulintas yang baik }\end{array}$ \\
\hline $\begin{array}{l}\text { 10. Tipe dan luas unit } \\
\text { kios }\end{array}$ & $\begin{array}{l}\text { Menyediakan tipe dan } \\
\text { dimensi kios yang ergonomis } \\
\text { serta efisien }\end{array}$ & $\begin{array}{l}\text { Tipe dan dimensi kios-kios yang tersedia harus } \\
\text { sesuai dengan karakter komoditas jualan }\end{array}$ \\
\hline $\begin{array}{l}\text { 11. Efektifitas } \\
\text { pemanfaatan ruang }\end{array}$ & $\begin{array}{l}\text { Memperbanyak proporsi luas } \\
\text { ruang yang bisa dijual } \\
\text { (sellable area) }\end{array}$ & $\begin{array}{l}\text { Luas ruang jual, idealnya sekitar } 65 \% \text { dari total } \\
\text { luas bangunan pasar. }\end{array}$ \\
\hline 12. Zoning & $\begin{array}{l}\text { 1. Menata zone komoditas } \\
\text { untuk mengatur alur } \\
\text { pengunjung guna } \\
\text { meningkatkan aksesibilitas } \\
\text { ke semua unit jual } \\
\text { 2. Mengefisienkan } \\
\text { penyediaan utilitas, } \\
\text { terutama jaringan air bersih } \\
\text { dan air kotor } \\
\text { 3. Memudahkan pengunjung } \\
\text { untuk menemukan area } \\
\text { berdasarkan komoditas }\end{array}$ & $\begin{array}{l}\text { 1. Zona komoditas inti (yang paling dicari } \\
\text { pengunjung) diletakkan di tempat paling sulit } \\
\text { dijangkau dan berperan sebagai magnet yang } \\
\text { menarik pengunjung untuk } \\
\text { menghidupkan zona komoditas lainnya. } \\
\text { 2. Unit-unit jual yang membutuhkan utilitas air } \\
\text { bersih dan utilitas air kotor harus diletakkan } \\
\text { berdekatan } \\
\text { 3. Zone komoditas tertentu harus diberi } \\
\text { penanda tertentu agar memudahkan dikenali } \\
\text { pengunjung }\end{array}$ \\
\hline $\begin{array}{l}\text { 13. Aksesbilitas dan } \\
\text { sistem } \\
\text { sirkulasi }\end{array}$ & $\begin{array}{l}\text { 1. Menjamin semua unit pasar } \\
\text { dapat dijangkau oleh } \\
\text { pengunjung } \\
\text { 2. Memudahkan pengunjung } \\
\text { untuk menjangkau lantai- } \\
\text { lantai atas pasar }\end{array}$ & $\begin{array}{l}\text { 1. Pintu masuk dan sirkulasinya, harus } \\
\text { dirancang agar semua area pasar mudah } \\
\text { dijangkau } \\
\text { 2. Zone komoditas inti ditempatkan pada area } \\
\text { tertentu agar menarik pengunjung untuk } \\
\text { menghidupkan zone komoditas lainnya } \\
\text { 3. Unit-unit jual harus mendapatkan } \\
\text { aksesbilitas visual yang memadai dari } \\
\text { pengunjung } \\
\text { 4. Escalator bisa disediakan untuk pasar dengan } \\
\text { ketinggian } 4 \text { lantai atau lebih } \\
\text { 5. Jalur sirkulasi dirancang secara hirarki dan } \\
\text { disediakan simpul sirkulasi pada jalur } \\
\text { sirkulasi yang panjang }\end{array}$ \\
\hline
\end{tabular}




\begin{tabular}{|c|c|c|}
\hline Isu & Tujuan & Kriteria \\
\hline 14. Penghawaan & $\begin{array}{l}\text { Menciptakan ruang-ruang } \\
\text { pasar yang segar dan tidak } \\
\text { pengap }\end{array}$ & $\begin{array}{l}\text { 1. Area pubik dan sirkulasi harus dirancang } \\
\text { dengan memaksimalkan sirkulasi udara } \\
\text { silang } \\
\text { 2. Penghawaan di dalam unit jual bisa } \\
\text { menggunakan sirkulasi udara buatan (kipas } \\
\text { angin) }\end{array}$ \\
\hline 15. Pencahayaan & $\begin{array}{l}\text { Menciptakan ruang-ruang } \\
\text { pasar yang terang dan tidak } \\
\text { terkesan gelap }\end{array}$ & $\begin{array}{l}\text { 1. Area publik dan sirkulasi harus dirancang } \\
\text { untuk mengoptimalkan pencahayaan alami } \\
\text { 2. Pencahayaan di dalam unit jual bisa } \\
\text { menggunakan lampu terutama untuk } \\
\text { menerangi komoditas yang dijual }\end{array}$ \\
\hline 16. Fasilitas umum & $\begin{array}{l}\text { Menyediakan fasilitas umum } \\
\text { yang mendukung fungsi pasar }\end{array}$ & $\begin{array}{l}\text { 1. Fasilitas umum minimal yang harus } \\
\text { disediakan adalah KM/WC, mushola, kantor } \\
\text { pengelola dan ruang serba guna } \\
\text { 2. Fasilitas umum lain dapat ditambahkan } \\
\text { sesuai kebutuhan }\end{array}$ \\
\hline 17. Utilitas air bersih & $\begin{array}{l}\text { Menyediakan sarana air bersih } \\
\text { yang memadai bagi pedagang } \\
\text { komoditas basah }\end{array}$ & $\begin{array}{l}\text { 1. Zona-zona komuditas basah harus diletakkan } \\
\text { berdekatan untuk efisiensi utilitas air bersih } \\
\text { 2. Outlet air bersih harus disediakan di tiap unit } \\
\text { daging/ikan, sedangkan untuk komoditas } \\
\text { sayur/buah satu outlet air bersih bisa } \\
\text { digunakan bersama-sama }\end{array}$ \\
\hline 18. Utilitas air kotor & $\begin{array}{l}\text { Menciptakan ruang-ruang } \\
\text { pasar yang bersih dan tidak } \\
\text { becek }\end{array}$ & $\begin{array}{l}\text { 1. Saluran pembuangan air kotor harus } \\
\text { dibedakan pada zona komoditas basah } \\
\text { 2. Fasilitas fisik pada zona basah harus } \\
\text { dirancang untuk meminimalkan genangan air } \\
\text { kotor }\end{array}$ \\
\hline 19. Persampahan & $\begin{array}{l}\text { Menciptakan pasar yang } \\
\text { bersih dari sampah }\end{array}$ & $\begin{array}{l}\text { Tempat penampungan sampah (tertutup) harus } \\
\text { disediakan dan ditempatkan juga pada area } \\
\text { aktifitas publik }\end{array}$ \\
\hline
\end{tabular}

Tabel 6 Isu, tujuan dan kriteria pembangunan Pasar Banjarsari Pekalongan tidak melupakan aspek ciri khas/karakter lokal Kota Pekalongan

\begin{tabular}{l|l|l}
\multicolumn{1}{c|}{ Isu } & \multicolumn{1}{c}{ Tujuan } & \multicolumn{1}{c}{ Kriteria } \\
\hline 1. Tampilan fisik & $\begin{array}{l}\text { Fisik pasar menampilkan } \\
\text { karakter arsitektur lokal }\end{array}$ & $\begin{array}{l}\text { Perancangan bangunan pasar Banjarsari, } \\
\text { sebaiknya menggunakan elemen-elemen } \\
\text { arsitektur lokal kota Pekalongan }\end{array}$ \\
\hline $\begin{array}{l}\text { 2. Pengalaman } \\
\text { berkunjung }\end{array}$ & $\begin{array}{l}\text { Menyajikan pengalaman yang } \\
\text { menarik bagi pengunjung saat } \\
\text { berbelanja }\end{array}$ & $\begin{array}{l}\text { Zoning dan jalur-jalur sirkulasi harus dirancang } \\
\text { sedemikian rupa agar pengunjung pasar } \\
\text { Banjarsari bisa menikmati suasana pasar } \\
\text { dengan segala ke-khasan kota Pekalongan }\end{array}$ \\
\cline { 2 - 4 } & $\begin{array}{l}\text { Unit jual bisa dirancang dengan menjadikan } \\
\text { barang dagangan sebagai atraksi visual }\end{array}$ \\
\hline 3. Ruang sosio kultural & $\begin{array}{l}\text { Menjadikan pasar tradisional } \\
\text { sebagai ruang sosio-kultural } \\
\text { bagi warga kota }\end{array}$ & $\begin{array}{l}\text { Tersedianya ruang-ruang sosio-kultural, baik } \\
\text { permanen atau temporer yang dapat } \\
\text { menampung aktivitas sosial atau seni } \\
\text { pertunjukan rakyat di pasar Banjarsari }\end{array}$
\end{tabular}

\section{PENUTUP}

\subsection{Simpulan}

Berdasarkan hasil pembahasan di atas, maka dapat disimpulkan beberapa hal sebagai berikut:

1) Pasar harus segera dibangun kembali dengan mengakomodir masukan dan harapan dari pedagang serta konsumen 
2) Untuk pedagang lama yang masih memiliki hak atas toko/kios/los sebelum pasar Banjarsari terbakar, hendaknya perlu dipertimbangkan untuk dapat menempati kembali pasar dengan gratis

3) Penataan parkir dan rekayasa lalu lintas dibuat lebih baik lagi, sehingga memudahkan masyarakat yang berkunjung, memudahkan pedagang dalam melakukan proses bongkar muat dan tidak menimbulkan kemacetan di sekitar pasar

4) Tersedia fasilitas dan petugas kesehatan pada pasar yang baru

\subsection{Rekomendasi untuk Pemerintah Kota Pekalongan}

Secara keseluruhan, hasil penelitian ini memberikan beberapa rekomendasi untuk Pemerintah Kota Pekalongan, agar Pasar Banjasari yang baru nanti menjadi pasar ideal yang sesuai dengan harapan konsumen dan pedagang, sekaligus menjadi icon kebanggaan masyarakat kota Pekalongan, berikut rekomendasinya:

1) Dalam melakukan pembangunan ulang pasar Banjarsari Pekalongan, hendaknya memperhatikan 2 (dua) aspek berikut:

a. Pemenuhan aspek standar fungsional sebuah pasar

b. Tidak melupakan aspek ciri khas/karakter lokal Kota Pekalongan

2) Revitalisasi pasar Banjarsari, merupakan kesempatan untuk:

a. Menerapkan sistem retribusi berbasis teknologi informasi/e-retribusi (hasil kajian Dewan Riset Daerah kota Pekalongan tahun 2017), sehingga pemasukan PAD kota Pekalongan dapat lebih optimal

b. Mengoptimalkan fungsi pasar tradisional (pasar Banjarsari) dengan tidak meletakan berdampingan dengan pasar modern.

c. Menata ulang manajemen pasar

d. Meningkatkan kualitas dan kuantitas SDM yang terlibat

\section{DAFTAR PUSTAKA}

Kotler, Philip, dkk, 2000, Manajemen Pemasaran dengan pemasaran efektikf dan Profitable, cetakan Kedua, Gramedia Pustaka Utama, Jakarta.

Leksono, S, 2009. Runtuhnya Modal Sosial, Pasar Tradisional, Malang: CV Citra Malang

Peraturan Presiden Republik Indonesia Nomor 112 Tahun 2007 tentang Penataan dan Pembinaan Pasar Tradisional, Pusat Perbelanjaan dan Toko Modern

Materi Agus S. Ekomadyo yang disampaikan pada acara Temu Ilmiah IPLBI 2012

Stanton, William J. (2002). Fundamentals of Marketing. McGraw Hill, Singapore.

Tjiptono, Fandy. 2005. "Pemasaran Jasa"; Penerbit Bayumedia Publishing, Malang

Undang-Undang Republik Indonesia Nomor 7 tahun 2014 tentang Perdagangan.

Danisworo, 2002 pengertian revitalisasi, (online) http://makalahdanskripsi.blogspot.com/ 2009.03/definifi-revitalisasi.html

http://jateng.tribunnews.com/.../4028-lapak-pedagang-pasar-banjarsari-pekalongan-habis$\underline{t e \ldots}$

26 Feb 2018

https://mediaurbanplanner.wordpress.com/2018/03/25/pengertian-revitalisasi/

Laretna, Adishakti, 20012, " Revitalisasi Bukan Sekedar "Beautification", Urdi Vol.13, www.urdi.org (Urban and Reginal Development Institute). 